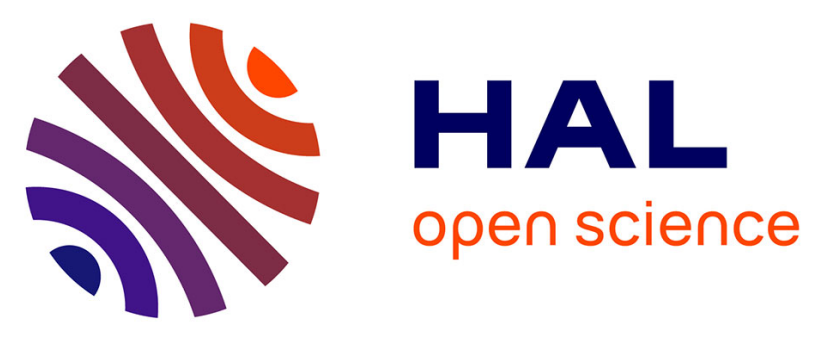

\title{
Analysis of VLF/LF transmitter signals during the minimum of solar activity in the year 2018
}

Mohammed Boudjada, Vanessa Weingril, Hans Ulrich Eichelberger, Pier Francesco Biagi, Xuemin Zhang, Werner Magnes, Konrad Schwingenschuh, Alexander Rozhnoi, Patrick H. M. Galopeau, Anita Ermini, et al.

\section{To cite this version:}

Mohammed Boudjada, Vanessa Weingril, Hans Ulrich Eichelberger, Pier Francesco Biagi, Xuemin Zhang, et al.. Analysis of VLF/LF transmitter signals during the minimum of solar activity in the year 2018. EGU General Assembly 2020, May 2020, Virtual Meeting, Germany. 10.5194/egusphereegu2020-13456 . insu-03054183

\section{HAL Id: insu-03054183 \\ https://hal-insu.archives-ouvertes.fr/insu-03054183}

Submitted on 11 Dec 2020

HAL is a multi-disciplinary open access archive for the deposit and dissemination of scientific research documents, whether they are published or not. The documents may come from teaching and research institutions in France or abroad, or from public or private research centers.
L'archive ouverte pluridisciplinaire HAL, est destinée au dépôt et à la diffusion de documents scientifiques de niveau recherche, publiés ou non, émanant des établissements d'enseignement et de recherche français ou étrangers, des laboratoires publics ou privés. 


\section{Analysis of VLF/LF transmitter signals during the minimum of solar activity in the year 2018}

M.Y. Boudjada1, V. Weingril', H.U. Eichelberger ${ }^{1}$, P.F. Biagi ${ }^{2}$, X. Zhang ${ }^{3}$, W. Magner ${ }^{1}$, K. Schwingenschuh', A. Rozhnoi ${ }^{4}$, P.H.M. Galopeau ${ }^{5}$, A. Ermini ${ }^{6}$, H. Lammer ${ }^{1}$, R. Colella ${ }^{2}$, B. Besser ${ }^{1}$ and M. Stachel ${ }^{1}$

${ }^{1}$ Space Research Institute, Austrian Academy of Sciences, Graz, Austria

2 Department of Physics, University of Bari, Bari, Italy

${ }^{3}$ Institute of Earthquake Science, China Earthquake Administration, Beijing, China

${ }^{4}$ Institute of the Earth Physics, RAS, Moscow, Russia

${ }^{5}$ LATMOS-CNRS, Université Versailles Saint-Quentin-en-Yvelines, Guyancourt, France

${ }^{6}$ Department of Industrial Engineering, University of Tor Vergata, Rome, Italy 
We report on VLF/LF transmitter signals observed in the year 2018 during the minimum of solar activity. Those signals were recorded in Graz (Austria) using INFREP (Biagi et al., Nat. Hazards Earth Syst. Sci., 11, 2011) and UltraMSK (Schwingenschuh et al., Nat. Hazards Earth Syst. Sci., 11, 2011) systems. This leads us to record fourteen transmitter signals in the frequency range between $19 \mathrm{kHz}$ and up to $270 \mathrm{kHz}$. Six transmitter channels are common to both systems and are localized in Great-Britain (Anthorn, GBZ, 19.58kHz), Italy (Tavolara, ICV, $20.27 \mathrm{kHz}$ ), Germany (Rhauderfehn, $23.4 \mathrm{kHz}$, ) and Island (Keflavik, NRK, $37.5 \mathrm{kHz}$ ). Others are mainly LF broadcasting transmitters from Romania (Brasov, 153kHz), Luxembourg (Felsberg-Berus, 183kHz), Algeria (Berkaoui, $198 \mathrm{kHz}$ ), Monte-Carlo (Roumoules, 216kHz) and Tchecki (Lualualei, 270kHz). In the year 2018, the solar activity decreased reaching its minimum in the end of 2019. We emphasize in this work on three aspects: (a) C-flares related to the solar activity, (b) Kp-index linked to the geomagnetic activity, and (c) seismic events in the southern part of Europe, i.e. Greece and Italy. The dominant patterns observed on almost all transmitters are due to the solar flares. Geomagnetic activity is found to depend on the seasonal effect and mainly observed few weeks before and after the summer solstice in the northern hemisphere. Few earthquakes occurred in the southern part of Europe, in Greece ( 6 events) and in Italy (2 events) with a magnitude of $5.5 \mathrm{Mw}$ and depths less than $10 \mathrm{~km}$. We discuss the disturbances of VLF/LF transmitter signals prior to EQs occurrences, and their links to external effects. Our results are compared to recent investigations of Zhang et al. (Radio Sci., 52, 2017) and Rozhnoi et al. (Ann. Geophys., 37, 2019) concerning, respectively, the spatial distribution of VLF transmitter signals recorded by Demeter satellite, and the solar X-flare effects on VLF/LF transmitter signals. 
The observed channels recorded @ Graz_Station (+15.46E; 47.03N)

\begin{tabular}{|c|c|c|c|c|c|c|}
\hline & System & Code & $\begin{array}{c}\text { Freq. } \\
(\mathrm{Hz})\end{array}$ & Long. & Lat. & Location \\
\hline 1 & INFREP/ULTRA & GBZ & 019580 & $-3.28 \mathrm{E}$ & $54.91 \mathrm{~N}$ & UK, Anthorn \\
\hline 2 & INFREP/ULTRA & ICV & 020270 & $09.71 E$ & $40.91 \mathrm{~N}$ & Italy, Tavolara \\
\hline 3 & ULTRA & NPM & 021400 & $-158.13 E$ & $21.42 \mathrm{~N}$ & USA, Lualualei \\
\hline 4 & INFREP & HWU & 021750 & $01.24 \mathrm{E}$ & $46.71 \mathrm{~N}$ & France, Le Blanc \\
\hline 5 & INFREP/ULTRA & DHO & 023400 & $07.60 \mathrm{E}$ & $53.08 \mathrm{~N}$ & Germany, Rhauderfehn \\
\hline 6 & ULTRA & NAA & 024000 & $-67.28 \mathrm{E}$ & $44.65 \mathrm{~N}$ & USA, Cutler \\
\hline 7 & ULTRA & TBB & 026700 & 27.31E & $37.40 \mathrm{~N}$ & Turkey, Bafa \\
\hline 8 & INFREP/ULTRA & NRK & 037500 & $-22.56 \mathrm{E}$ & $64.02 \mathrm{~N}$ & Island, Keflavik \\
\hline 9 & ULTRA & ITS & 045900 & 14.43E & $37.12 \mathrm{~N}$ & Itaky, Niscemi \\
\hline 10 & INFREP & RRO & 153000 & $25.61 \mathrm{E}$ & $45.75 \mathrm{~N}$ & Romania, Brasov \\
\hline 11 & INFREP & EU1 & 183000 & $06.68 \mathrm{E}$ & $49.28 \mathrm{~N}$ & Luxembourg, Felsberg-Berus \\
\hline 12 & INFREP & $\mathrm{CH} 1$ & 198000 & $05.08 \mathrm{E}$ & $31.92 \mathrm{~N}$ & Algeria, Berkaoui/Ouargia \\
\hline 13 & INFREP & MCO & 216000 & $06.13 E$ & $43.78 \mathrm{~N}$ & Roumoules, Monte-Carlo \\
\hline 14 & INFREP & CZE & 270000 & $17.51 \mathrm{E}$ & $49.12 \mathrm{~N}$ & Tchecki, Lualualei \\
\hline
\end{tabular}




\section{Selected Seismic Events}

\begin{tabular}{|c|c|c|c|c|c|c|}
\hline Date & Time & Mag. & Lat. & Long. & $\begin{array}{c}\text { Depth } \\
(\mathbf{k m})\end{array}$ & Location \\
\hline 02.01 .2018 & $04: 24$ & 5.1 & $41.22 \mathrm{~N}$ & $22.86 \mathrm{E}$ & 06 & Greece \\
\hline 16.05 .2018 & $22: 30$ & 5.0 & $36.46 \mathrm{~N}$ & $22.96 \mathrm{E}$ & 10 & Southern Greece \\
\hline 25.06 .2018 & 05:14 & 5.5 & $36.72 \mathrm{~N}$ & 21.37E & 10 & Southern Greece \\
\hline 16.08.2018 & $18: 19$ & 5.3 & $41.89 \mathrm{~N}$ & $14.82 \mathrm{E}$ & 10 & Southern Italy \\
\hline 31.08.2018 & 07:12 & 5.1 & $39.28 \mathrm{~N}$ & $21.62 \mathrm{E}$ & 12 & Greece \\
\hline 17.09.2018 & $00: 24$ & 5.0 & $34.33 \mathrm{~N}$ & $26.50 \mathrm{E}$ & 10 & Crete, Greece \\
\hline 27.09.2018 & $10: 21$ & 5.2 & $36.74 \mathrm{~N}$ & 21.33E & 10 & Southern Greece \\
\hline 26.12.2018 & 02:19 & 5.0 & $37.53 \mathrm{~N}$ & $15.20 \mathrm{E}$ & 10 & Sicily, Italy \\
\hline
\end{tabular}




\section{Solar Acivity: C-Flare Occurrence}

\begin{tabular}{|l|c|c|c|c|}
\hline \multicolumn{1}{|c|}{ Date } & \multicolumn{4}{|c|}{ Detection of C-Flares } \\
\hline & GBZ & ICV & DHO & NRK \\
\hline 04.02 .2018 & Y & Y & N & Y \\
\hline 07.02 .2018 & N & N & N & N \\
\hline 12.02 .2018 & Y & N & N & Y \\
\hline 02.03 .2018 & N & N & N & N \\
\hline 30.03 .2018 & N & N & N & N \\
\hline 23.05 .2018 & Y & Y & Y & Y \\
\hline 28.05 .2018 & Y & Y & Y & Y \\
\hline 06.06 .2018 & Y & Y & N & Y \\
\hline 21.06 .2018 & Y & Y & Y & Y \\
\hline 05.07 .2018 & Y & Y & N & Y \\
\hline
\end{tabular}


Geomagnetic Activity: Kp-Index

\begin{tabular}{|c|c|c|c|c|c|}
\hline Date & Kp-index & \multicolumn{4}{|c|}{ Detection of C-Flares } \\
\hline 14.01 .2018 & 4.5 & N & N & N & N \\
\hline 15.01 .2018 & 4.7 & Y & N & N & N \\
\hline 27.02 .2018 & 5.0 & N & N & Y & N \\
\hline 18.03 .2018 & 6.0 & N & Y & N & N \\
\hline 20.04 .2018 & 6.0 & N & N & Y & N \\
\hline 05.05 .2018 & 5.7 & N & N & N & N \\
\hline 06.05 .2018 & 5.7 & N & N & Y & N \\
\hline 01.06 .2018 & 4.7 & Y & Y & Y & Y \\
\hline 25.06 .2018 & 4.9 & N & N & N & N \\
\hline 26.06 .2018 & 4.7 & Y & Y & Y & Y \\
\hline 26.08 .2018 & 7.2 & N & N & N & N \\
\hline 11.09 .2018 & 6.0 & N & N & N & N \\
\hline 07.10 .2018 & 5.1 & N & N & N & N \\
\hline 05.11 .2018 & 5.5 & N & N & N & N \\
\hline
\end{tabular}




\section{Main Outcomes}

- Seismic events

1. Eight EQs occurred in Greece (6) and in Italy (2) with a magnitude more than $5 \mathrm{Mw}$ and a depth in the order of $10 \mathrm{~km}$

2. Only ICV transmitter exhibits drop amplitude signal before EQs occurrence

3. Decrease of ICV signal is observed for 3 events $(25 / 06 ; 16 / 08 ; 26 / 12)$

- Solar activity

1. C-flares only occur in the first semester of $\mathbf{2 0 1 8}$

2. C-flares were simultaneously recorded (all transmitters) at three occasions (23/05; 28/05;21/05)

3. More than five C-flares were observed in signals of GBZ (6/10), ICV(5/10) and NRK (6/10) transmitters

4. Only two flares associated to DHO transmitter signal

- Geomagnetic activity

1. Kp-index $\sim 6.0$ during the year 2018

2. Only DHO transmitter signal exhibits a depence on geomagnetic activity 